\title{
A CAPACIDADE CIVIL INDÍGENA
}

\author{
CIVIL INDIGENOUS CAPACITY
}

JULIANNE HOLDER DA CÂMARA SILVA FEIJÓ ${ }^{1}$

\begin{abstract}
RESUMO: Partindo de relevantes transformações introduzidas pela atual Constituição Federal no direito indigenista pátrio, o presente ensaio se debruça sobre a delicada questão da capacidade civil indígena, através de uma análise evolutiva da legislação histórica, perpassando pelo processo de redemocratização brasileira, quando correntes filosóficas pluralistas e multiculturais influenciaram uma revolução sem precedentes no tratamento jurídico destinado ao ser indígena pelo Estado brasileiro. Sob essa forte influência, a atual Constituição Federal estruturou um sólido sistema de reconhecimento e proteção à diversidade sóciocultural brasileira, reconhecendo aos índios o direito a continuar reproduzindo seu estilo de vida tradicional, ao mesmo tempo em que thes reconhece como importante segmento social formador da identidade cultural do povo brasileiro, abandonando definitivamente a necessidade de aculturação do indígena como pressuposto necessário para o exercício pleno de sua capacidade civil.

PALAVRAS-CHAVE: Índios; Multiculturalismo; Capacidade Civil.
\end{abstract}

ABSTRACT: Building on relevant changes introduced by the current Federal Constitution in indigenous paternal right, this essay focuses on the delicate issue of Indian civil capacity, through an evolutionary analysis of the historic legislation, passing by the Brazilian democracy, where current philosophical pluralist and multicultural process influenced an unprecedented revolution in the legal treatment to be indigenous to the Brazilian State. Under this strong influence, the current Federal Constitution structured a solid system of recognition and protection of Brazilian socio-cultural diversity, recognizing the Indians the right to continue playing their traditional lifestyle, while recognizing them as important social segment trainer the cultural identity of the Brazilian people, definitely abandoning the need for acculturation of indigenous as necessary precondition for the full exercise of their civil capacity.

KEYWORDS: Indians; Multiculturalism; Civil Capacity.

\footnotetext{
Artigo recebido em 07.08.2014. Pareceres emitidos em 18.09.2014 e 22.09.2014.

Artigo aceito para publicação em 06.10.2014.

${ }_{1}^{1}$ Professora da Universidade Federal Rural do Semi-árido (UFERSA), Rio Grande do Norte, Campus Mossoró. Mestre em Direito Constitucional pela Universidade Federal do Rio Grande do Norte (UFRN), Campus Natal. Advogada. Graduada pela Universidade Federal do Rio Grande do Norte (UFRN), Campus Natal. julianne.holder@ufersa.edu.br
} 
SUMÁRIO: Introdução; 1. Catequese, Civilização e Dominação Socio-cultural: O triste histórico do direito indigenista no Brasil; 1.1 Legislação Histórica; 1.2 A Constituição Brasileira de 1988: O Brasil nos caminhos do multiculturalismo libertário; 2. A Capacidade Civil Indígena: evolução e perspectivas; Conclusões; Referências.

SUMMARY: Introduction; 1 . Catechism, Civilization and Socio-cultural Domination: the sad history of indian law in Brazil; 1.1 Legislation Historical; 1.2 The Brazilian Constitution of 1988: Brazil in the ways of libertarian multiculturalism; 2. Civil Indigenous Capacity: progress and prospects; Conclusions; References.

\section{INTRODUÇÃO}

A questão da capacidade civil indígena atormenta os juristas brasileiros desde a época colonial, entretanto nem sempre fora dado ao tema uma solução adequada. A verdade é que, desde a Coroa portuguesa, o Estado nunca soube ao certo que tratamento deferir aos ameríndios, se reconhecia eficácia e validade aos usos e costumes tradicionais ou se exigia a prática do 'direito oficial' pelos gentios.

O fato é que a tradição civilista brasileira fazia confusão a cerca da diferença cultural, entre índios e não-índios, e a capacidade para o exercício dos atos da vida civil, como se não pertencer à cultura dominante fosse sinônimo de incapacidade para conduzir a própria vida e o seu patrimônio. Concluía-se, até bem pouco tempo atrás, que enquanto o indígena não estivesse integrado à civilização, em abandono de suas tradições para viver como um perfeito cidadão brasileiro, ele não possuiria o discernimento apropriado para gerenciar, por si só, a própria vida ou seus pertences, necessitando, pois, ser representado, o que acabava reclamando a necessária intervenção de um órgão estatal que Ihe assistisse nos atos da vida civil.

Dessa forma, toda a legislação tutelar do índio possuía como objetivo específico promover sua integração à comunhão nacional, civilizando-o, de modo que a condição de índio era compreendida como transitória, fadada a extinção, posto que todo autóctone se integraria, abandonando seu modo de vida 'primitivo'. A assistência estatal perduraria apenas enquanto a civilização não fosse alcançada pelo indígena.

Era o chamado paradigma da assimilação cultural, verdadeira política oficial do Governo brasileiro que visava à integração e aculturação gradativa dos povos indígenas. No entanto, uma vez civilizado e integrado à sociedade envolvente perderia a condição de índio e poderia, enfim, exercer plenamente os atos da vida civil, tornando-se senhor de sua vida e de seus pertences.

Este cenário somente se modificaria com a Constituição Federal de 1988, quando o vetusto paradigma assimilacionista deu lugar à garantia de reprodução física e cultural, assegurando-se às comunidades indígenas, dentre outros, o direito à perpetuidade de suas tradições milenares, línguas, religiosidade e costumes, abandonando-se definitivamente o fantasma da integração. Após a Constituição de 88 o índio brasileiro ganhou o direito a 
continuar sendo índio, sem que sua condição cultural diferenciada acarrete qualquer prejuízo ao gozo de todos os direitos inerentes a qualquer integrante do povo brasileiro, e sem que o uso desta cidadania culmine na perda de sua identidade tradicional.

Dessa forma, o presente artigo visa demonstrar como esse contexto de transformações filosóficas, políticas e jurídicas, introduzidas no Ordenamento Pátrio pela novel Carta constitucional, permitiu ao indígena se tornar plenamente capaz para o exercício dos atos da vida civil, abandonando decisivamente a tutela-incapacidade inaugurada desde o período colonial, demonstrando que a garantia de reprodução cultural anda de mãos dadas com o reconhecimento da capacidade civil plena dos indígenas.

Do contrário estar-se-ia trazendo novamente à baila a necessidade de aculturação e incorporação como condição para que os silvícolas possam usufruir direitos inerentes à cidadania, postura totalmente rechaçada pela atual Constituição que assegura não só aos indígenas, mas a todas as minorias étnicas nacionais, o direito de continuar reproduzindo suas tradições seculares ao mesmo tempo em que os reconhece como legítimos integrantes do povo brasileiro, destinatários de qualquer direito conferido a qualquer de seus membros.

\section{CATEQUESE, CIVILIZAÇÃO E DOMINAÇÃO SOCIO-CULTURAL: O TRISTE HISTÓRICO DO DIREITO INDIGENISTA NO BRASIL}

Desde a chegada dos colonizadores portugueses e, a partir de então, por todo o período que se segue, até a promulgação da Constituição Federal (CF) de 1988, percebe-se que a aculturação do indígena fez-se uma constante no ordenamento jurídico brasileiro. De início com a finalidade de catequizar para 'salvar a alma do bom selvagem' (a dominação religiosa), em seguida objetivando a 'civilização' dos indígenas, dado o seu estado de 'primitividade', e consequente integração ao modo de vida 'civilizado' (a dominação cultural).

De uma forma ou de outra, a política oficial do Governo brasileiro sempre se dedicou à integração do indígena à comunidade envolvente, com a consequente perda das características tradicionais dos silvícolas ${ }^{2}$. Em razão desse fato, considerava-se o indígena uma condição transitória, fadada à extinção ${ }^{3}$. Acreditava-se sinceramente que o índio desejaria e necessitaria se integrar, que seria seu objetivo abandonar a vida primitiva que levava.

Não era permitido ao índio continuar sendo índio, ele deveria ser 'civilizado' e, alcançando essa civilização, perderia sua condição de índio e todas as prerrogativas que essa qualidade poderia propiciar. Percebe-se claro

\footnotetext{
${ }^{2}$ Sem negligenciar as diferenças conceituais entre os termos índios, silvícolas, aborígenes, autóctones, gentios, íncolas dentre outras formas utilizadas para designar o indígena, utilizaremos todas essas expressões como sinônimas, apenas para fins didáticos.

${ }^{3}$ SOUZA FILHO, Carlos Frederico Marés de. O Direito Envergonhado - O Direito e os Índios no Brasil. Revista IIDH, vol 15. Costa Rica: Instituto Interamericano de Direitos Humanos, 1990, p. 158. Disponível em: http://www.corteidh.or.cr/tablas/R06852-5.pdf. Acesso em 17 jul. 2014.
} 
tal objetivo ao nos debruçarmos sobre a legislação histórica brasileira, o que passaremos a analisar.

\subsection{Legislação Histórica}

Cartas Régias de 1808 (maio, novembro e dezembro) declaravam guerra aos índios Botocudos do Paraná, então província paulista, aos índios Bugres de São Paulo e aos Botocudos do vale do Rio Doce, Minas Gerais, que não se submetessem às Leis reais, permitindo aos milicianos que os aprisionassem para fins de servidão, por 15, 15 e 10 anos, respectivamente, podendo o cativeiro se estender até a sua 'pacificação'. As referidas Cartas Régias explicavam que não se tratava de escravizar os gentios, mas de educá-los à convivência da sociedade 'doce e pacífica'4.

O fim da escravidão indígena, fruto das guerras de 1808, veio através da Lei de 27 de outubro de 1831 que, no entanto declarou a orfandade dos índios cativos, que deveriam ser entregues a um Juiz de órfãos que fornecer-lhes-ia educação e sustento, até que viessem a ter um trabalho remunerado ${ }^{5}$. Mais tarde, um Decreto de 03 de junho de 1833, encarregou os juízes de órfãos da administração dos bens dos silvícolas libertos do cativeiro. Esses dois Atos conduziram à equivocada interpretação de que todos os índios do País seriam incapazes de gerir o seu patrimônio e a sua vida, necessitando da assistência estatal para tanto, inaugurando a malfadada tutela orfanológica.

Observe que a Lei de 1831 e o Decreto de 1833 se destinavam unicamente aos gentios liberados da servidão iniciada nas guerras de 1808 , não contemplando os silvícolas que viviam em liberdade. Entretanto, os juristas da época acharam por bem enquadrar todo e qualquer índio sob a tutela orfanológica ${ }^{6}$.

A Constituição do Império (1824) de início nada previu acerca dos índios, tendo, posteriormente, um Ato Adicional (1832) introduzido a competência do Governo quanto à catequização e civilização dos autóctones (art. 11, § $5^{\circ}$, Lei 16 de 12 de agosto de 1832).

O Decreto 8.072/1910, responsável pela criação do SPI (Serviço de Proteção ao Índio) ${ }^{7}$, altera profundamente a política indigenista do País, deixando de lado as preocupações religiosas substituiu a catequese por uma política integracionista, fundada na crença evolucionista da humanidade, quando o ser indígena era considerado uma condição primitiva, fadada à civilização, estágio mais 'avançado' da evolução humana.

\footnotetext{
${ }^{4}$ SOUZA FILHO, Carlos Frederico Marés de. O Renascer dos Povos Indígenas para o Direito. Curitiba: Juruá Editora, 2008, p. 56.

${ }^{5}$ SOUZA FILHO, op. cit., 1990, p. 155.

${ }^{6}$ SOUZA FILHO, op. cit., 2008, p. 94.

${ }^{7}$ O SPI fora inicialmente designado Serviço de proteção aos índios e localização de trabalhadores nacionais, transformou-se simplesmente em SPI em 1918, era ligado ao Ministério da Agricultura, indústria e comércio, tendo sua direção conferida ao Marechal Candido Mariano Randon.
} 
Acreditava-se sinceramente que a "civilização" era o melhor para o índio e por ele desejada. Então toda a legislação brasileira a partir deste momento, até o período anterior à Constituição Federal de 1988, voltava-se à gradativa incorporação do indígena à civilização, o que fatalmente conduziria ao desaparecimento dos aborígenes do País. É o que a doutrina convencionou chamar de paradigma da assimilação cultural, ou paradigma assimilacionista, ou integracionista ${ }^{\text {. }}$. A ideia era tornar o índio um autêntico cidadão brasileiro.

Neste particular, a criação do SPI baseava-se na política de integração dos povos indígenas à cultura nacional, na expectativa de suplantar as culturas indígenas 'primitivas'. Observe que a dizimação da cultura indígena era, então, uma política oficial do Governo! Entretanto, e contraditoriamente, o diploma (Decreto 8.072/1910) previa a demarcação das Terras Indígenas (TI) (art. 11) e o respeito às terras, à organização interna, hábitos e instituições das tribos (art. $2^{\circ}, \S 2^{\circ}$ e $\S 4^{\circ}$ ).

O Código Civil de 1916 (art. 6 , IV e parágrafo único) preconizando à incapacidade civil relativa do indígena ${ }^{9}$, enquanto não integrados à civilização, criou o regime tutelar, a ser disciplinado em lei especial. Essa regulação se deu através do Decreto 5.484 de 27.06.1928, que dentre outras coisas previu a necessária representação dos índios pelo Estado (na figura do SPI) a fim de validar os atos por eles praticados, sob pena de nulidade. A incapacidade cessaria a medida que os aborígenes fossem se integrando à civilização (art. $5^{\circ}$ e $7^{\circ}$ ).

A Constituição brasileira de 1934 foi a primeira a tratar dos direitos indígenas, assegurando-lhes a posse de suas terras ${ }^{10}$ e atribuindo à União a competência para legislar a cerca da incorporação do silvícola à comunhão nacional $^{11}$. A Constituição de 1946 retoma o dispositivo, retirado na CF de 1937, que defere à União a competência para legislar sobre a incorporação do silvícola à comunhão nacional (art. $5^{\circ}, \mathrm{XV},{ }^{\prime}{ }^{\prime}$ '), dispositivo este mantido nas Constituições de 1967 (art. 8', XVII, 'o') e na Emenda n¹ de 1969. Claro então, que a incorporação do indígena à cultura dominante tratava-se de política oficial do Governo brasileiro, assegurado em instrumento constitucional.

Foi somente com a promulgação da Constituição Federal de 1988 que esse quadro se modificou, representando um marco decisivo para o direito indigenista do País, operando uma transformação sem precedentes no relacionamento índio-Estado brasileiro.

\footnotetext{
${ }^{8}$ SOUZA FILHO, op. cit., 1990, p. 161.

${ }^{9}$ Frise-se que desde o início, Clovis Beviláqua, mentor do CC de 1916 fora veementemente contra ao regime tutelar instituído pelo diploma uma vez tratar-se de instituto do direito de família, em nada compatível com a situação indígena, um universo jurídico aparte, que deveria ser regulado em legislação específica (SOUZA FILHO, op. cit., 2008, p. 98).

${ }^{10}$ Art 129 - Será respeitada a posse de terras de silvícolas que nelas se achem permanentemente localizados, sendo-lhes, no entanto, vedado aliená-las.

${ }^{11}$ Art. $5^{\circ}$ - "Compete privativamente à União: (...) XIX - legislar sobre: (...) $m$ - incorporação dos silvícolas à comunhão nacional".
} 
A novel Carta constitucional rompe definitivamente com o paradigma da assimilação cultural e civilização dos indígenas, estruturando um sólido sistema de proteção à diversidade cultural brasileira, valorizando os diversos grupos étnicos responsáveis pela construção do patrimônio cultural brasileiro. A partir de 88 as preocupações do Estado não objetivam mais a civilização e engajamento dos silvícolas à comunhão envolvente, mas sim a proteção de sua identidade cultural.

A Constituição de 88 foi a primeira Carta brasileira a dedicar um capítulo ${ }^{12}$ à regulação dos direitos e interesses indígenas, estruturando um sólido sistema de proteção à sua singularidade cultural, reconhecendo sua organização social, seus costumes, religião, línguas, crenças e tradições, assegurando-lhes o direito a reprodução física e cultural. Trocando em miúdos, a CF de 88 garantiu ao índio o direito a ser índio e a continuar reproduzindo seu modo de vida particular, tal como sempre fez, vivendo seus costumes e tradições sem o fantasma da aculturação forçada ${ }^{13}$.

\subsection{A Constituição Brasileira de 1988: O Brasil nos caminhos do multiculturalismo libertário}

O Estado Liberal de Direito, inaugurado com o pós revolução francesa e independência norte-americana, arrimava-se nas ideias iluministas de objetividade científica, individualismo e racionalismo, compreendendo a sociedade como algo homogêneo, estático e uniforme, sem espaço para a alteridade nem para o culturalmente diferente. Tudo o que era diverso dos padrões de uma sociedade "moderna" capitalista estaria fadado ao gradativo desaparecimento e compulsiva absorção pela "sociedade envolvente".

Neste contexto o ser indígena era compreendido como uma condição provisória, destinada ao desaparecimento e à assimilação social. Foi dentro desta perspectiva que grande parte da legislação brasileira, voltada à tutela do ser indígena, se estruturou. Vigorava o paradigma da assimilação cultural, arrimado em uma ideologia político-filosófico de que o ser humano se apresentava em diferentes níveis evolutivos, sendo a civilização o Estado mais avançado e caminho natural a ser trilhado pelos povos tribais 'primitivos' ${ }^{14}$.

No entanto, com a gradativa transformação do Estado de Direito em Estado Constitucional de Direito, e consequente positivação constitucional de um catálogo de direitos fundamentais, o princípio da dignidade humana foi alçado a valor nuclear do Ordenamento Jurídico, perpassando todos os aspectos do universo jurídico e social, realizando neles uma revolução sem precedentes.

Materializar a dignidade humana passou a significar mais do que garantir liberdades individuais e a igualdade formal, objetivos perseguidos pelas

\footnotetext{
${ }^{12}$ Capítulo VIII, art. 231-232, dentro do título VIII 'da ordem social'.

13 SOUZA FILHO, op. cit., 2008, p. 107.

${ }^{14}$ Inclusive, lembre-se que o Estatuto do Índio, Lei 6.001/1973, em vigor até hoje, adota o paradigma assimilacionista de aculturação indígena, com "o propósito de preservar a sua cultura e integrá-los, progressiva e harmoniosamente, à comunhão nacional" (art. $1^{\circ}$ ).
} 
revoluções liberais, passando a expressar o exercício da diferença. Dignidade é poder ser diferente sem que isso acarrete a perda de direitos. Foi então que se compreendeu a necessidade de dar proteção as formas culturais diferenciadas de certos grupos tradicionais, percebendo-se que garantir a dignidade humana para esses grupos significava dar proteção ao seu especial modo de vida, assegurando sua perpetuidade cultural.

Foi a partir daí que se passou a questionar o caráter universal dos direitos humanos, surgindo a dicotomia universalismo $x$ relativismo cultural. O primeiro, correspondendo à visão clássica, compreendia que o conteúdo dos direitos fundamentais, seu significado, seria universal, válido para qualquer ser humano em qualquer contexto. Já os relativistas apontam a tendência da uniformidade como um aspecto da dominação cultural, imposta pela compreensão norte-americana e eurocentrista de mundo ${ }^{15}$.

Deixando as polêmicas de lado, o fato é que a nossa Carta constitucional, inspirada nas tendências de constitucionalização dos direitos culturais ${ }^{16}$, estruturou uma seção dedicada à cultura (arts. 215 e 216), estendendo sua proteção às manifestações das culturas populares indígenas e afro-brasileiras e de outros grupos formadores do processo civilizatório nacional, reconhecendo expressamente que as formas de expressão e manifestação cultural desses grupos consubstanciam o patrimônio cultural brasileiro, merecedor de proteção pelo Estado brasileiro.

A nova dogmática constitucional visa preservar a diversidade cultural do País, reconhecendo que o Brasil é uma nação multicultural e pluriétnica, formada por uma riquíssima variedade de populações tradicionais que merecem ter seu modo de vida secular e sua cultura singular preservados uma vez que contribuíram, e ainda contribuem, para a formação da identidade do povo brasileiro. Aliás, o reconhecimento de que compomos uma "sociedade pluralista e sem preconceitos" resta expressamente evidenciada em seu preâmbulo que, apesar de desprovido de força normativa possui uma incontestável função hermenêutica integradora do texto constitucional, revelando seus valores mais contundentes ${ }^{17}$.

Assim, quilombolas, indígenas, seringueiros e toda uma sorte de populações que vivem um estilo de vida tradicional ganham espaço na tutela

\footnotetext{
${ }^{15}$ PIOVESAN, Flávia. Direitos Humanos e o Direito Constitucional Internacional. 11. ed., São Paulo: Saraiva, 2010. Passim.

${ }^{16}$ Neste cenário de transformações ideológicas, políticas e jurídicas, a Constituição Federal de 1988, ao nascer no Ordenamento Pátrio, vai dar seguimento a uma tendência surgida no início do século passado de elevar os direitos culturais ao status constitucional. Primeiramente positivada na Constituição mexicana de 1917 e em seguida na de Weimar (Alemanha) de 1919, os direitos culturais resumiam-se à proteção aos direitos autorais e a liberdade de expressão, bem aos moldes liberais de liberdades individuais. Vide SILVA, José Afonso da. Ordenação Constitucional da cultura. São Paulo: Malheiros, 2001, p. 39.

${ }^{17} \mathrm{O}$ papel do preâmbulo como instrumento de interpretação constitucional fora reconhecido pelo Supremo Tribunal Federal em sede da ADI 2.649, Relatora Min. Carmem Lúcia, julgamento em 08.05.2008.
} 
constitucional à diversidade cultural. Percebe-se, em verdade, que em nenhum dispositivo consta expressamente a opção constitucional pelo multiculturalismo, como fez a maioria das constituições dos demais países latinos, entretanto, tal escolha resta clara e evidente em uma análise sistemática e holística da Carta Magna - que reconhece a importante participação de diferentes grupos étnicos e sociais no processo de formação da identidade cultural do povo brasileiro - e a opção pelo pluralismo decorrente de seu preâmbulo.

A Constituição de 1988 concedeu proteção às manifestações culturais dos afro-descendentes, incumbindo o Poder Público de proteger tais referências culturais $^{18}$. A Constituição ainda atribuiu aos remanescentes das comunidades quilombolas o direito de propriedade sobre os seus territórios ${ }^{19}$, conferindo, de forma inédita no Ordenamento Jurídico do País, proteção aos descendentes dos antigos escravos, deixados à margem das iniciativas governamentais desde a abolição da escravatura em 1888, quando os quilombos passaram da proibição a uma realidade simplesmente desconsiderada.

Ressalte-se que a CF, no $\S 5^{\circ}$ do art. $216^{20}$, declara tombados todos os documentos e os sítios detentores de reminiscências históricas dos antigos quilombos, tendo, ainda, no caput, determinado que todos os bens de natureza material e imaterial portadores de referência à identidade, memória e ação dos diversos grupos formadores da sociedade brasileira, constituem nosso patrimônio cultural.

Da mesma forma, reconhecendo a necessidade de preservação de uma minoria étnica nacional, a Constituição Federal estipulou uma série de direitos e garantias em prol da conservação da singularidade cultural indígena, perfilhando em seu art. 231 e parágrafos ${ }^{21}$, o direito dos índios em manter sua

\footnotetext{
${ }^{18}$ Art. 215. "(...) § $1^{\circ}$ - O Estado protegerá as manifestações das culturas populares, indígenas e afro-brasileiras, e das de outros grupos participantes do processo civilizatório nacional. (...)". Art. 216. "Constituem patrimônio cultural brasileiro os bens de natureza material e imaterial, tomados individualmente ou em conjunto, portadores de referência à identidade, à ação, à memória dos diferentes grupos formadores da sociedade brasileira, nos quais se incluem: I - as formas de expressão; II - os modos de criar, fazer e viver; III - as criações científicas, artísticas e tecnológicas; IV - as obras, objetos, documentos, edificações e demais espaços destinados às manifestações artístico-culturais; $\mathrm{V}$ - os conjuntos urbanos e sítios de valor histórico, paisagístico, artístico, arqueológico, paleontológico, ecológico e científico (...)".

19 Art. 68 do Ato das Disposições Constitucionais Transitórias: "Aos remanescentes das comunidades dos quilombos que estejam ocupando suas terras é reconhecida a propriedade definitiva, devendo o Estado emitir-Ihes os títulos respectivos".

${ }^{20}$ Art. 216. "(...) $\S 5^{\circ}$ - Ficam tombados todos os documentos e os sítios detentores de reminiscências históricas dos antigos quilombos."

${ }^{21}$ Art. 231. "São reconhecidos aos índios sua organização social, costumes, línguas, crenças e tradições, e os direitos originários sobre as terras que tradicionalmente ocupam, competindo à União demarcá-las, proteger e fazer respeitar todos os seus bens. $\S 1^{\circ}$ - São terras tradicionalmente ocupadas pelos índios as por eles habitadas em caráter permanente, as utilizadas para suas atividades produtivas, as imprescindíveis à preservação dos recursos ambientais necessários a seu bem-estar e as necessárias a sua reprodução física e cultural, segundo seus usos, costumes e tradições. $\S 2^{\circ}$ - As terras tradicionalmente ocupadas pelos índios destinam-se a sua posse
} 
organização social, seus costumes, línguas, crenças e tradições, além de resguardar os direitos originários ${ }^{22}$ sobre as terras que tradicionalmente ocupam, assegurando-os o usufruto exclusivo das riquezas nelas existentes.

A proteção constitucional das minorias étnicas brasileiras vai mais além do que o simples reconhecimento da identidade cultural singular, garantindo aos membros de tais grupos sociais os mesmos direitos, deveres e oportunidades conferidas a qualquer cidadão brasileiro, dado que são integrantes do 'povo brasileiro', destinatários do rol de direitos e garantias fundamentais do ser humano, assegurados pelo Estado Brasileiro a qualquer de seus membros, sem que o gozo desses direitos implique qualquer perda de identidade cultural ou prerrogativas inerentes à sua condição jurídica especial ${ }^{23}$.

Percebe-se, então, que o maior direito assegurado pela Carta aos silvícolas foi o direito a ser índio, reproduzindo sua cultura e tradições seculares, perpetuando ${ }^{24}$ seu estilo de vida tradicional sem que isso acarrete qualquer prejuízo ao gozo de direitos enquanto membro do povo brasileiro.

\section{A CAPACIDADE CIVIL INDÍGENA: EVOLUÇÃO E PERSPECTIVAS}

A capacidade jurídica plena das pessoas naturais relaciona-se à possibilidade de adquirir direitos e assumir obrigações pessoalmente, sem a intervenção de quem quer que seja para tanto. Nos ensina Nelson Rosenvald ${ }^{25}$ que a capacidade jurídica se divide em duas vertentes: a Capacidade de direito (ou de gozo), relacionada a aptidão para titularizar relações jurídicas (ser sujeito de direitos), conferida à todas as pessoas naturais nascidas com vida; e a capacidade de fato (ou de exercício), correspondente à aptidão para, pessoalmente, praticar os atos da vida civil, exercendo por si só seus direitos ${ }^{26}$.

permanente, cabendo-Ihes o usufruto exclusivo das riquezas do solo, dos rios e dos lagos nelas existentes (...)".

${ }^{22}$ A expressão "Direitos originários sobre as terras que habitam" liga-se ao reconhecimento, pelo Ordenamento Jurídico brasileiro, da tradicional ocupação da terra pelos autóctones desde épocas imemoriais, que remontam à colonização do País, quando em $1^{\circ}$ de abril de 1680 o Alvará Régio os outorgou tal legitimidade. De lá para cá, a tendência nacional em todas as Constituições, foi a manutenção do reconhecimento de que o direito da posse indígena sobre suas terras é congênito, restando o Alvará de 1680 ainda em vigor, posto que nunca fora revogado.

${ }^{23}$ Neste Particular, reza a Declaração da ONU sobre Povos Indígenas, de 2007, assinada pelo Brasil: "Artigo - 2 Os povos e as pessoas indígenas são livres e iguais a todos os demais povos e pessoas e têm o direito a não ser objeto de nenhuma discriminação no exercício de seus direitos fundado, em particular, em sua origem ou identidade indígena".

${ }_{24}$ Aqui abro um parêntese para esclarecer que a perpetuidade cultural não significa uma intangibilidade ou um apartheid cultural, a convivência, mistura e influência de culturas diversas sempre foi um fato histórico, responsável pela reprodução cultural e pelo enriquecimento humano. A proteção constitucional à identidade cultural indígena não almeja a estagnação e o engessamento de culturas milenares como se fossem um museu vivo, mas apenas livrar da interferência ruinosa com que o Estado brasileiro atuou sobre esses grupos forçando um choque cultural e uma dominação vertical. Liberta-se enfim, o índio deixando que ele escolha o seu caminho.

${ }^{25}$ ROSENVALD, Nelson; FARIAS, Cristiano Chaves de. Direito Civil - Teoria Geral. 8. ed., Rio de Janeiro: Lúmen Júris, 2010, p. 248.

${ }^{26}$ GAGLIANO, Pablo Stolze; PAMPLONA FILHO, Rodolfo. Novo Curso de Direito Civil - Parte Geral. Vol. I. São Paulo: Saraiva, 2010, p. 132. 
As limitações à capacidade jurídica das pessoas naturais se dão justamente através da capacidade de exercício, quando determinadas condições pessoais do indivíduo (orgânicas ou psicológicas) impedem a realização pessoal dos atos da vida civil, conduzindo à necessidade de integração dessa falta de capacidade de exercício, através dos institutos jurídicos da assistência e da representação. Dessa forma, a incapacidade civil seria a ausência da possibilidade de exercício dos próprios direitos por si só ou por procurador habilitado (dado que não teria capacidade para outorgar poderes de representação).

Pessoas com capacidade jurídica plena não necessitam ser assistidos ou representados para que possam exercitar seus direitos. Já pessoas sem capacidade jurídica plena, muito embora possuam a capacidade de gozo, não poderão praticar sozinhas os atos da vida civil, sob pena de invalidade de tais atos. Vale dizer que as pessoas incapazes merecem um tratamento especial, em virtude de sua falta de compreensão total, ou relativa, dos atos da vida civil, de modo que essa incompreensão seja suprida, igualando-o aos sujeitos plenamente capazes.

É o Código Civil quem estabelece as limitações à capacidade de exercício das pessoas naturais, elencando em seu art. $3^{\circ}$ os absolutamente incapazes, que precisam ser representados; e os relativamente incapazes (art. $4^{\circ}$ ) cuja incapacidade se circunscreve apenas a determinados atos, quando se faz necessária a assistência. Os atos praticados pelos absolutamente incapazes, sem a necessária representação, padece do vício da nulidade desde sua origem; já os atos praticados pelos relativamente incapazes sem a necessária assistência conduz à anulabilidade de tais atos, desde que declarados pelo Poder Judiciário, em decisão com efeitos ex nunc.

Expostos os contornos gerais do instituto da capacidade civil das pessoas naturais, passemos à análise da capacidade civil dos indígenas.

Conforme demonstrado alhures, a política oficial de relacionamento entre o Estado brasileiro e seus indígenas sempre fora a dominação cultural, uma aculturação forçada. De início com finalidades religiosas, através da catequização, posteriormente por meio do processo de civilização. Tal opção política lançava seus reflexos em diversos aspectos jurídicos do direito indigenista.

Em primeiro lugar fora responsável pela instituição da tutela-incapacidade ${ }^{27}$ do Estado sobre os silvícolas existentes no território nacional. Compreendia-se que, sendo os índios uma categoria não civilizada, não pertencente ao processo de comunhão nacional, não possuiriam capacidade para gerir suas próprias vidas e a de seus bens, sendo, pois, incapazes frente à legislação civil, motivo

\footnotetext{
${ }^{27}$ Se faz de bom alvitre não confundir a tutela incapacidade - presente na legislação anterior e que não fora recepcionada pela novel Carta, por se arrimar no paradigma da assimilação cultural - com a tutela proteção, ainda presente na CF, em seu art. 231, ao determinar o dever da União (na figura da FUNAI) de zelar pelos direitos e bens dos indígenas.
} 
pelo qual deveriam ser assistidos pelo Estado, na figura de um órgão especialíssimo, inicialmente o juiz de órfão, posteriormente o SPI (Sistema de Proteção ao Índio), substituído, finalmente, pela FUNAI (Fundação Nacional do Índio) em 1967.

A noção de tutela-incapacidade teve início com os Decretos de 03.06.1833 e 27.10.1831 (Brasil império), aliado ao Regulamento 143 de 15.03.1842, que criou o sistema da tutela orfanológica ${ }^{28}$, atribuindo aos juízes de órfãos poderes especiais em relação à pessoa e aos bens dos índios ${ }^{29}$, capaz de elidir, inclusive, o pátrio poder (atual poder familiar) ${ }^{30}$. Os juízes de órfão, além de poderes para gerir o patrimônio e a pessoa dos silvícolas, possuíam atribuições jurisdicionais, de primeira e segunda instância, com poderes para conhecer e julgar as causas envolvendo questões indígenas.

O Decreto $n^{\circ} 426$, de 24.07.1845, chamado de Regulamento acerca das Missões de Catequese e Civilização dos índios, assim dispunha: Art. $5^{\circ}$ "A capacidade, de fato, dos índios sofrerá restrições prescritas nesta lei, enquanto não se incorporarem eles à sociedade civilizada." ${ }^{\text {. }}$.

O Código Civil de 1916 passa a determinar expressamente a incapacidade relativa dos índios para os atos da vida civil (art. $6^{\circ}$, IV), sujeitando-os ao regime tutelar, que deveria ser regulada em legislação específica, salientando que esta incapacidade cessaria na medida em que fossem se adaptando à civilização do País (parágrafo único). Esse novo regime tutelar não se confundia com a tutela orfanológica, dado que esta apresentava feição nitidamente privatista, arrimado em institutos do direito de família, sendo o tutor aquele que decide e administra os bens, enquanto que a tutela estabelecida pelo CC de 1916 possuía cunho publicista, relacionado a devida representação do Estado para dotar de validade os atos praticados pelos índios, o tutor seria aquele que assiste ${ }^{32}$.

A regulação específica exigida pelo Estatuto civil veio em 1928, através do Decreto 5.484, que expressamente liberava os silvícolas da tutela orfanológica vigente nas Ordenações do Reino, reputando nulos os atos praticados pelos índios sem a devida assistência do Estado, que na época se dava através do SPI. Frise-se que a extinção da tutela orfanológica pelo referido Decreto não afastou o equívoco da assimilação.

\footnotetext{
${ }^{28}$ Para maiores detalhes, consultar item 1.1.

${ }^{29}$ MIRANDA, A. Gursen de. Coordenador. O Direito e o Índio. Belém: Editora Cejup, 1994, p. 34.

${ }^{30}$ Carlos Frederico Marés (Op. cit., 2008, p. 92) conta a triste história da índia Helena que, considerada incapaz de gerir a própria vida apenas pelo fato de ser índia, perdeu a guarda de seu filho menor, Antônio Solimões, para um Juiz de Órfãos, em 25 de outubro de 1898, sob o argumento de que "era uma selvagem", "não dominando o português" e, "como conseqüência, não poderia gerir a sua própria vida, muito menos a de seu filho".

${ }_{31}$ O referido Decreto criou nas Províncias o cargo de Diretor Geral de Índios, além do cargo de diretor de aldeia. Estes últimos possuía competência para demarcar as terras indígenas, representar os índios na qualidade de procurador legal, passando, ainda, a deter as atribuições e poderes dos juízes de órfãos, com exceção da competência jurisdicional, (SOUZA FILHO, op. cit., 2008, p. 96).

${ }_{32}$ SOUZA FILHO, op. cit., 2008, p. 101-105.
} 
Quando foi editado o Estatuto do Índio (Lei 6.001/1973), revogando o Decreto 5.484/1928, fora mantido o regime tutelar previsto no CC de 1916, que tratava o silvícola como relativamente incapaz ${ }^{33}$, cessando a sua incapacidade a medida que fosse se adaptando à civilização do País, revelando a transitoriedade com que a condição indígena era tratada na época ${ }^{34}$. Protegia-se para integrar, acreditando-se sinceramente que a integração fosse o melhor para o índio, e uma vez integrado deixaria de ser índio e perderia os direitos inerentes a esta condição ${ }^{35}$.

Destaque-se que o El condiciona, inclusive, o gozo de direitos civis e políticos pelos índios à integração deste à comunhão nacional (art. $5^{\circ}$, parágrafo único): "O exercício dos direitos civis e políticos pelo índio depende da verificação das condições especiais estabelecidas nesta Lei e na legislação pertinente". Esses requisitos não estão expressos no diploma, o que nos leva a crer que sejam as condições necessárias para se obter a liberação do regime tutelar e aquisição da plena capacidade civil, conforme veremos adiante.

O El expressamente dividia os indígenas em 'isolados', 'em vias de integração' e 'integrados', de acordo com o grau de contato que mantivessem com a sociedade envolvente e consequente assimilação de seus hábitos, sendo certo que conferia plena capacidade para os atos da vida civil apenas aos indígenas reconhecidamente integrados, mantendo sob o regime tutelar os ainda não integrados (art. $7^{\circ}$ ).

A liberação do regime tutelar dependia de solicitação do interessado junto ao órgão de assistência, dependendo de homologação judicial e do preenchimento dos seguintes requisitos (art. $9^{\circ}$ ): Ser maior de 21 anos, ter conhecimento da língua portuguesa, ter habilitação para o exercício de atividade útil na comunhão nacional e razoável compreensão dos usos e costumes da comunhão nacional ${ }^{36}$.

Saliente-se que, no famoso caso da demarcação da Terra Indígena Raposa Serra do Sol, o Supremo Tribunal Federal (STF) se posicionou no sentido

\footnotetext{
${ }^{33}$ Pablo Stolze Gagliano (Op. cit., 2010, p. 144) defende que o regime tutelar estabelecido pelo estatuto do índio considerava o indígena absolutamente incapaz e que, tendo o Código civil de 2002 deixado a regulação da capacidade civil indígena para a legislação especial, estando o El em pleno vigor, vigoraria hoje a incapacidade absoluta dos aborígenes.

${ }^{34}$ Lei 6.001/1973: Art. $7^{\circ}$ Os índios e as comunidades indígenas ainda não integrados à comunhão nacional ficam sujeito ao regime tutelar estabelecido nesta Lei. § $2^{\circ}$ Incumbe a tutela à União, que a exercerá através do competente órgão federal de assistência aos silvícolas. Art. $8^{\circ}$ São nulos os atos praticados entre o índio não integrado e qualquer pessoa estranha à comunidade indígena quando não tenha havido assistência do órgão tutelar competente.

${ }^{35}$ Perceba que, uma vez integrados, os índios deixariam de ser índios e, consequentemente, suas terras deixariam de ser indígenas, o que fatalmente conduziria à sua reversão ao domínio público.

${ }^{36} \mathrm{~A}$ tutela do El conduziu à absurdos tamanhos que acabavam por justificar verdadeiros cerceamentos do direito à locomoção, como aconteceu com o cacique Mário Juruna que, convidado no exterior, por entidades defensoras dos direitos humanos, para expor a situação indígena no Brasil, teve sua saída do País obstada pelo Ministro do Interior, então chefe hierárquico do presidente da FUNAI, tendo o caso ido parar no judiciário que, por fim, autorizou o líder indígena à sair do Território brasileiro, (SOUZA FILHO, op. cit., 2008, p. 105).
} 
de que a integração do indígena não faz cessar sua condição de índio, permanecendo os direitos inerentes a esta condição ${ }^{37}$. A integração tem apenas o condão de afastar a necessidade de perícia a fim de averiguar a capacidade penal do silvícola. De fato, julgados da Suprema Corte, bem como do Superior Tribunal de Justiça, apontam alguns elementos como identificador da integração do indígena, o que conduz à sua plena imputabilidade penal, apuráveis de pronto pelo magistrado, sem a necessária realização de laudo antropológico, tais como: grau de escolaridade, título de eleitor, liderança criminosa, habilitação para dirigir, dentre outros.

A partir de 05 de outubro de 1988, quando o índio no Brasil passou a ter o direito a ser índio, não há mais o que se falar em incapacidade civil ${ }^{38}$, primeiramente em virtude do abandono do paradigma assimilacionista em favor da garantia de reprodução física e cultural de minorias étnicas, restando garantido aos indígenas a manutenção de seu estilo de vida tradicional sem o fantasma da 'civilização',39.

Em segundo lugar por ser conferido aos silvícolas, sem qualquer exigência adicional, todos os direitos fundamentais destinados a qualquer integrante do povo brasileiro, dentre eles a cidadania. Em terceiro, por não ter a novel Constituição exigido qualquer representação ou assistência a fim de legitimar os atos praticados pelos índios.

\footnotetext{
${ }^{37}$ Pet 3388, Relator: Min. CARLOS BRITTO, Tribunal Pleno, julgado em 19.03.2009, DJe-181.

${ }^{38}$ Registre-se que, em suas justificativas, o PL 2057, voltado a regular o Estatuto das Sociedades Indígenas, ainda não aprovado pelo Congresso Nacional, expressamente abandona a concepção de incapacidade civil do indígena para compreendê-lo como apto plenamente ao exercício dos atos da vida civil.

${ }^{39}$ Vide decisão do STJ neste sentido: “(...)Os instrumentos normativos e as Constituições anteriores à Carta de 1988 concebiam os índios como relativamente incapazes. A capacidade plena somente era adquirida conforme os autóctones adquirissem outros costumes, progredindo do seu estágio social para o estágio da 'avançada civilização branca'. Por esta razão, estabeleciam que os índios deveriam ser incorporados à comunhão nacional, para assim serem reconhecidos no pleno exercício dos direitos civis. Enquanto não incorporados à comunhão nacional, os indígenas permaneciam sob a tutela do órgão indigenista oficial - inicialmente o Serviço de Proteção ao Índio (SPI) e, posteriormente, a Fundação Nacional do Índio (FUNAI) - encarregado do auxílio no processo de assimilação dos índios pela sociedade nacional. (...) Com o advento da Constituição de 1988, este cenário alterou-se substancialmente. Isso porque restou reconhecida a diversidade cultural e importância da valorização da cultura dos grupos étnicos formadores da sociedade brasileira, dentre os quais se incluem os indígenas (...) Na esteira do reconhecimento da diversidade cultural, aboliu-se a política integracionista das populações indígenas. A partir de 1988, não mais se pretende que os silvícolas percam as características, costumes, línguas e tradições que lhe são inerentes para serem incorporados a uma pretensa cultura nacional. Inovou o texto constitucional também ao reconhecer, em seu artigo 232, que os índios, suas comunidades e organizações são partes legítimas para ingressar em juízo em defesa de seus direitos e interesses. Ao reconhecer aos indígenas capacidade postulatória e, por conseqüência, capacidade civil, porque consoante se extrai do artigo $7^{\circ}$ do Código de Processo Civil, toda pessoa que se acha no exercício de seus direitos, tem capacidade para estar em juízo - lógica segundo a qual 'quem tem o mais, tem o menos' -, restou extinto o instituto da tutela sobre os povos indígenas, porquanto não é possível conceber que a FUNAI administre os bens e responda pelos atos de quem tem plena capacidade civil. (...)". (Rec. Especial n 1.026.942-SC, Relatora: Min. Denise Arruda, 03.02.2010).
} 
E finalmente, em face do art. 232 que assegura aos índios, suas comunidades e organizações, legitimidade para ingressar em juízo na defesa de seus direitos e interesses, não exigindo representação ou assistência de quem quer que seja ${ }^{40}$.

As associações indígenas surgem nesse contexto como uma forma alternativa de articulação política dos silvícolas, uma nova maneira de organizar suas demandas de modo a se relacionar com o Governo e suas políticas, bem como com entidades da sociedade civil comprometidas com a questão indígena do Brasil ${ }^{41}$. As associações e organizações indígenas ainda cumprem um importante papel de inserção dos indígenas na cultura não-índia, realizando a intercessão entre os dois universos culturais distintos em que o aborígene necessita transitar ${ }^{42}$.

Com as associações indígenas a FUNAl deixa de ser a única instituição responsável por atender as demandas e necessidades dos índios brasileiros que passam a se organizar legalmente e, com respaldo na Constituição, e a pleitear seus interesses, em juízo e fora dele, sem necessitar ficar à mercê de órgão do Governo que nem sempre atua em sintonia com os anseios e aspirações dos gentios.

Voltando à questão da capacidade civil, se extrai do artigo $7^{\circ}$ do Código de Processo Civil que toda pessoa que se achar no exercício de seus direitos (capacidade de exercício!), tem capacidade para estar em juízo na defesa de seus interesses. Partindo do pressuposto de que 'quem pode o mais, pode o menos' - ou seja, se podem os indígenas estar em juízo sem a assistência do Estado é porque possuem capacidade para exercer, por si só, os atos da vida civil - o STJ decidiu, em julgado recente, pela plena capacidade civil do indígena $^{43}$, uma vez que, não sendo permitido aos incapazes estar em juízo sem a devida representação, em possuindo os silvícolas a prerrogativa de estar em juízo por si só, claro está sua plena capacidade civil (de exercício e de gozo).

O STJ, inclusive, se posicionou expressamente no sentido de que não cabe mais à FUNAI responder pelos atos praticados pelos silvícolas que causem danos à terceiros, nem cabe-lhe mais tutelar os bens dos silvícolas posto que são eles plenamente capazes para os atos da vida civil.

\footnotetext{
${ }^{40}$ Art. 232. "Os índios, suas comunidades e organizações são partes legítimas para ingressar em juízo em defesa de seus direitos e interesses, intervindo o Ministério Público em todos os atos do processo".

${ }^{41}$ INSTITUTO SOCIOAMBIENTAL (ISA). Almanaque Socioambiental - Parque Indígena do Xingu 50 anos. São Paulo: Instituto Socioambiental, 2011, p. 191.

${ }^{42}$ Merece destaque a Atix (associação Terra Indígena Xingu) que representa os povos habitantes do Parque Indígena do Xingu nas demandas de seu interesse; a IPEAX (Instituto de Pesquisa Etno Ambiental do Xingu) voltada para a gestão do atendimento à saúde dos povos do Alto-Xingu (ISA, 2011, p. 195).

${ }^{43}$ STJ, RE No 1.026.942- SC, Rel. Denise Arruda, Publicação em 03.02.2010.
} 
É bem verdade que o Código civil, em seu art. $4^{\circ}$, parágrafo único, deixou a regulação da capacidade civil dos indígenas para a legislação específica, o que conduz os intérpretes desavisados ao Estatuto do Índio (Lei 6.001/73) por ser a Lei de regência especial dos íncolas. No entanto, esquecem que o El fora editado em momento anterior à promulgação da CF de 88 , quando ainda vigorava o malfadado paradigma da integração cultural, presente no ordenamento jurídico brasileiro desde o período colonial e que fora suplantado apenas com a Novel Constituição e seu paradigma de reprodução física e cultural das minorias étnicas nacionais.

À guise do exposto, tendo a CF de 88 abandonado o modelo integracionista, temos que toda a legislação indigenista anterior a 5 de outubro de 1988, deverá ser interpretada segundo seus ditames e, em sendo contrária a ela, por óbvio, estará revogada por falta de recepção na nova Ordem Constitucional. Dessa forma, fácil concluir que diversos dispositivos do Estatuto do índio, por estarem atrelados ao padrão assimilacionista, não foram recepcionados pela Constituição hodierna, não tendo, pois, qualquer aplicação.

Quanto a legislação especial destinada à regulação da capacidade civil dos índios, como exigiu o Código Civil de 2002, forçoso concluir pela inconstitucionalidade do referido dispositivo, uma vez que a própria CF de 1988 não exigiu qualquer representação ou assistência aos índios para que estes possam estar em juízo, ou seja, reconhecendo sua capacidade civil plena, não poderia um Código, legislação infraconstitucional, impor restrições ao que não sofreu limitação pela própria Carta Constitucional. Compreender de outra forma seria um atropelo às decisões políticas e jurídicas assumidas pelo Constituinte de 88, numa flagrante inconstitucionalidade.

Percebe-se, pois, mais uma grande inovação perpetrada pela Constituição brasileira de 1988 no que tange ao direito indigenista pátrio, rompendo com uma tradição histórica de nossa legislação: a (in)capacidade civil dos silvícolas. $\mathrm{O}$ art. 232 da CF inaugura uma nova fase do direito indigenista brasileiro, não exigindo mais do índio que se faça representar por órgão estatal especial (hoje a FUNAI) para que os atos por ele praticados se revistam de legitimidade. A partir de 1988 o índio não só ganhou o direito constitucional a ser índio como também ganhou a plena capacidade civil para gerir sua própria vida e a de seus bens.

Ressalte-se que a capacidade civil é a regra, enquanto a incapacidade civil é a exceção, devendo ser estabelecida por lei justamente por afetar o pleno exercício dos direitos da personalidade da pessoa natural ${ }^{44}$. No entanto, independentemente de existir regulação da matéria, o fato é que a própria Constituição não exigiu representação ou assistência para o exercício dos direitos conferidos aos povos indígenas.

\footnotetext{
${ }^{44}$ DINIZ, Maria Helena. Curso de Direito Civil Brasileiro - Teoria Geral do Direito Civil. São Paulo: Saraiva, 2005, p. 148.
} 
Pelo contrário, possibilitou aos índios e suas organizações o ingresso no judiciário sem a representação ou assistência de quem quer que seja. Se a própria CF não limitou a capacidade civil dos autóctones, não seria concebível que um ato normativo infraconstitucional o fizesse, dado que o ingresso de indígenas no judiciário, por si só, fora opção do próprio constituinte originário, um direito da personalidade que não poderá ser limitado por norma hierarquicamente inferior.

O artigo 232 ainda determina que caberá ao Ministério Público intervir em todos os atos do processo, como custos legis.

É de salientar que, fora os índios e suas comunidades e organizações, também a União (através da FUNAI) e o Parquet, possuem legitimidade para defender em juízo os interesses das comunidades indígenas. A primeira em razão da tutela-proteção estabelecida no caput do art. 231, o segundo em virtude do dever institucional previsto no art. 129, V.

Não se objetiva mais a incorporação do silvícola ao nosso modus vivendi, pelo contrário, protege-se o seu direito de viver conforme suas tradições culturais, a viver como índio, sem que isso acarrete qualquer perda dos direitos conferidos a qualquer brasileiro. Não é mais necessário deixar de lado a condição de índio a fim de que se possa gozar das prerrogativas inerentes à vida civil. Cidadania e condição indígena não são mais qualidades excludentes, mas agregadoras.

\section{CONCLUSÕES}

A Constituição Federal brasileira de 1988, inspirada em valores pluralistas e multiculturais, que rondavam o cenário internacional em plena consolidação do Neoconstitucionalismo, operou uma revolução jurídica, filosófica e ideológica no tratamento ao ser indígena, sem precedentes na história constitucionalista pátria. Abandonando o paradigma da assimilação cultural, assim como a política oficial do Governo voltada à 'civilização' e gradativa incorporação do silvícola à sociedade envolvente, a novel Carta política estruturou um sólido sistema de proteção à diversidade cultural brasileira, reconhecendo e protegendo a identidade cultural de minorias étnicas, dentre elas os povos indígenas, negligenciadas por séculos de imposição social, garantindo, antes de tudo, a sua reprodução física e cultural, o direito a viver conforme suas tradições e costumes imemoriais.

Dentre as garantias asseguradas aos indígenas pela atual ordem constitucional ressalta-se o direito a ser índio e a continuar reproduzindo seu modo de vida tradicional sem que essa identidade cultural diferenciada acarrete qualquer perda de direitos, reconhecendo não só que os índios encontram-se aptos a gozar de todas as prerrogativas conferidas à qualquer integrante do povo brasileiro, sem a necessidade de se 'civilizar', ao mesmo tempo em que continuam usufruindo das prerrogativas inerentes ao status jurídicos de indígena, conciliando definitivamente cidadania com singularidade cultural, conceitos até bem pouco tempo atrás excludentes. 
Dessa forma, se antes da Constituição de 88 o índio precisaria perder suas origens culturais, se 'civilizando', para, em fim, alcançar a cidadania, o que trazia implicações diretas para o reconhecimento jurídico de sua capacidade civil, agora o ordenamento pátrio deixa de exigir a aculturação do silvícola como condição para que possa gerir seu patrimônio e sua pessoa, bem como para usufruir de direitos civis e políticos, tornando despiciendo qualquer representação ou assistência de quem quer que seja dada a plena capacidade civil que alcançou após a Constituição de 88.

Afora o abandono do paradigma da assimilação cultural, outro forte argumento a favor da plena capacidade civil do índio liga-se ao disposto do artigo 232 da Carta constitucional, que os possibilita, sem exigir qualquer representação, ingressar por conta própria no judiciário na defesa de seus direitos e interesses. Com arrimo neste argumento do STJ, em recentes julgados, vêm decidindo pela plena capacidade civil dos indígenas, uma vez que, ostentar a capacidade ativa processual implica necessariamente na presença da capacidade civil plena da pessoa natural. Concluir de outra forma acabaria por fazer letra morta da Constituição da República que optou por reconhecer a legitimidade processual dos índios para estar em juízo sem a representação do Estado, outrora exigida.

\section{REFERÊNCIAS}

BARBOSA, Carla Gonçalves Antunha; BARBOSA, Marco Antônio; BARBOSA, João Mítia Antunha. Direito a Diferença na Sociedade da Informação: Os direitos indígenas na Constituição brasileira. Revista do Instituto dos Advogados de São Paulo, São Paulo, vol. 20, 2007.

BARRETO, Helder Girão. Direitos Indígenas: Vetores constitucionais. Curitiba: Juruá Editora, 2008.

BARROSO, Luiz Roberto. Neoconstitucionalismo e Constitucionalização do direito (O triunfo tardio do Direito Constitucional no Brasil). In: NETO, Cláudio Pereira de Souza; SARMENTO, Daniel. A Constitucionalização do Direito: fundamentos teóricos e aplicações específicas. Rio de Janeiro: Lúmen Júris, 2007.

BONAVIDES, Paulo. Curso de Direito Constitucional. 13. ed., São Paulo: Malheiros, 2003. . Curso de Direito Constitucional. 15. ed., São Paulo: Malheiros, 2008.

. Do País Constitucional ao País Neocolonial - A derrubada da Constituição e a recolonização pelo golpe de Estado institucional. 3. ed., São Paulo: Malheiros, 2004.

. Teoria do Estado. 7. ed., São Paulo: Malheiros, 2008.

BRASIL. Constituição da República dos Estados Unidos do Brasil de 16 de julho de 1934. Disponível em: <http://www.planalto.gov.br/ccivil_03/Constituicao/Constitui\%C3 \%A7ao34.htm>. Acesso em 01 jun. 2012.

. Constituição da República dos Estados Unidos do Brasil de 10 de novembro de 1937. Disponível em: <http://www.planalto.gov.br/ccivil_03/Constituicao/Constitui\% C3\%A7ao37.htm>. Acesso em 01 jun. 2012.

. Constituição da República dos Estados Unidos do Brasil de 10 de setembro de 1946. Disponível em: <http://www.planalto.gov.br/ccivil_03/Constituicao/Constitui\% C3\%A7ao46.htm>. Acesso em 01 jun. 2012. 
. Constituição da República Federativa do Brasil de 15 de março de 1967. Disponível em: <http://www.planalto.gov.br/ccivil_03/Constituicao/Constitui\%C3\%A7 ao67.htm>. Acesso em 01 jun. 2012.

Constituição da República Federativa do Brasil de 05 de outubro de 1988. Disponível em: <http://www.planalto.gov.br/ccivil_03/Constituicao/Constituicao.htm>.

. Lei $n^{\circ} 601$ de 18 de setembro de 1850. Dispõe sobre as terras devolutas do Império. Disponível em: <http://www.planalto.gov.br/ccivil_03/Leis/LIM/LIM601.htm>. Acesso em: 01 jun. 2012.

Lei $n^{\circ} 3.071$ de 1 de janeiro de 1916. Dispõe acerca do Código Civil dos Estados Unidos do Brasil. Disponível em: <http://www.planalto.gov.br/ccivil_03/Leis/ L3071.htm>. Acesso em 01 jun. 2012.

. Lei $n^{\circ} 6.001$ de 19 de dezembro de 1973. Dispõe sobre o Estatuto do Índio. Disponível em: <http://www.planalto.gov.br/ccivil_03/Leis/L6001.htm>. Acesso em 02 jun. 2012.

CANOTILHO, José Joaquim Gomes. Direito Constitucional e Teoria da Constituição. Coimbra: Editora Almedina, 2002.

CASTRO, Carlos Roberto Siqueira. A Constituição Aberta e os Direitos Fundamentais - Ensaios sobre o constitucionalismo pós-moderno e comunitário. Rio de Janeiro: Forense, 2005.

CUNHA, Manoela Carneiro da. O Futuro da Questão Indígena. In: Estudos Avançados. São Paulo, abr. 1994. p. 121-136. Disponível em: <http://www.scielo.br/pdf/ea/v8n20/ v8n20a16.pdf>. Acesso em: 12 nov. 2008.

DANTAS, Fernando Antônio de Carvalho. As Sociedades Indígenas no Brasil e seus Sistemas Simbólicos de Representação: Os direitos de ser. In: SILVA, Letícia Borges da; OLIVEIRA, Paulo Celso de. Socioambientalismo - Uma realidade. Curitiba: Juruá, 2007. p. 89-109.

DINIZ, Maria Helena. Curso de Direito Civil Brasileiro - Teoria Geral do Direito Civil. São Paulo: Saraiva, 2005.

FEIJÓ, Julianne Holder da Câmara Silva; SILVA, Maria dos Remédios Fontes. Proteção à Identidade Indígena e Quilombola: Uma análise à luz do multiculturalismo e da abertura constitucional. Revista Constituição e Garantia de Direitos, Natal, vol. 04, ano II, fev./ago. 2011. Disponível em: <http://www.ccsa.ufrn.br/ojs/index.php/PPGD/ issue/view/40/showToc>.

Proteção à Identidade Cultural no Contexto do Neoconstitucionalismo e da Abertura Constitucional. Artigo publicado nos anais do Congresso Lusobrasileiro de Direito do Patrimônio Cultural. Ouro Preto, mar. 2011.

FEIJÓ, Julianne Holder da Câmara Silva. O Direito Penal e o Indígena: Aspectos acerca da imputabilidade penal e da competência judiciária. Revista jurídica In Verbis, Natal-RN, ano XIV, 25. ed., jan./jun. 2009.

FERRAREZO FILHO, Paulo. O Multiculturalismo nos Limites da Universalização dos Direitos Humanos e a Emergência de um Projeto de Solidariedade. In: Direitos Culturais. Disponível em: <http://srvapp2s.urisan.tche.br/seer/index.php/direitos culturais/ article/view/23/17>. Acesso em: 03 out. 2010.

FUNDAÇÃO NACIONAL DO ÍNDIO. Índios do Brasil. Disponível em: http://www.funai. gov.br/. Acesso em 04 maio 2012. 
GAGLIANO, Pablo Stolze; PAMPLONA FILHO, Rodolfo. Novo Curso de Direito Civil Parte Geral. Vol. I, São Paulo: Saraiva, 2010.

HESSE, Konrad. A força Normativa da Constituição. Porto Alegre: Fabris Editor, 1991. Tradução de Gilmar Ferreira Mendes.

. Constitución y Derecho Constitucional. In: BENDA, Ernst; MAIHOFER, Werner; VOGEL, Hans-Jochen; HESSE, Konrad; HEYDE, Wolfgang. Manual de Derecho Constitucional. 2. ed., Madri: Marcial, 2001.

Significado de los Derechos Fundamentales. In: BENDA, Ernst; MAIHOFER, Werner; VOGEL, Hans-Jochen; HESSE, Konrad; HEYDE, Wolfgang. Manual de Derecho Constitucional. 2. ed., Madrid: Marcial, 2001.

INSTITUTO SOCIOAMBIENTAL (ISA). Povos Indígenas do Brasil. Disponível em: $<$ http://pib.socioambiental.org/pt/c/direitos/estatuto-do-Indio/introducao>. Acesso em 05 jun 2014.

Almanaque Socioambiental - Parque Indígena do Xingu 50 anos. São Paulo: Instituto Socioambiental, 2011.

Declaração das Nações Unidas sobre os Direitos dos Povos indígenas. Disponível em: <http://pib.socioambiental.org/files/file/PIB_institucional/DECLARACAO_ DAS_NACOES_UNIDAS_SOBRE_OS_DIREITOS_DOS_POVOS_INDIGENAS.pdf > . Acesso em 15 jun. 2014.

MALLMANN, Germene. As Comunidades Remanescentes de Quilombo e o artigo 68 do ADCT: Propriedade da terra, reconhecimento e cidadania. In: SILVEIRA, Vladmir Oliveira da (Cord.). Revista Direito Brasileira (RDBras), São Paulo: Editora Revista dos Tribunais, ano 1, nº 1, jul./dez. 2011.

MELLO, Celso Antônio Bandeira de. Conteúdo Jurídico do Princípio da Igualdade. 3. ed., São Paulo: Malheiros, 2008.

MIRANDA, A. Gursen de. Coordenador. O Direito e o Índio. Belém: Editora Cejup, 1994. MIRANDA, Jorge. Manual de Direito Constitucional. Tomo II, 4. ed., Coimbra: Coimbra Editora, 2000.

PIOVESAN, Flávia. Direitos Humanos e o Direito Constitucional Internacional. 11. ed., São Paulo: Saraiva, 2010.

ROCHA, Ana Flávia (Org.). A Defesa dos Direitos Socioambientais no Judiciário. São Paulo: Instituto Socioambiental (ISA), 2003.

ROSENVALD, Nelson; FARIAS, Cristiano Chaves de. Direito Civil - Teoria Geral. 8. ed., Rio de Janeiro: Lúmen Júris, 2010.

SANTILLI, Juliana. Socioambientalismo e Novos Direitos: Proteção jurídica à diversidade biológica e cultural. São Paulo: Editora Peirópolis, 2005.

SANTOS, André Leonardo Copetti. A Diferença como Sintaxe Epocal da Pósmodernidade - Apontamentos filosóficos para uma tutela jurídica da diversidade. Revista Direitos culturais. Programa de Pós-graduação em Direito - Mestrado da URI, Campus de Santo Ângelo/RS. Vol. 5, no 9, jul./dez. 2010. p. 67-74. Disponível em: $<$ http://srvapp2s.urisan.tche.br/seer/index.php/direitosculturais/issue/view/23>. Acesso em 02 jun. 2011.

SANTOS, Boaventura de Sousa (Org.). Reconhecer para Libertar: Os caminhos do cosmopolitismo multicultural. Rio de Janeiro: Civilização Brasileira, 2003. Disponível em: <http://books.google.com.br>. Acesso em 26 jan. 2012. 
Por uma Concepção Multicultural dos Direitos Humanos. Rio de Janeiro: Contexto Internacional, vol. 23, jan./jun. 2001. p. 7-34. Disponível em: <http://www.boaventura desousasantos.pt/media/pdfs/Concepcao_multicultural_direitos_humanos_Contexto Internacional 01.PDF>. Acesso em: 22 maio 2011.

SANTOS FILHO, Roberto Lemos dos. Apontamentos sobre o Direito Indigenista. Curitiba: Juruá Editora, 2006.

SILVA, Américo Luís Martins da. Populações Indígenas ou Tradicionais. In: Direito do Meio Ambiente e dos Recursos Naturais. V. III, São Paulo: Editora Revista dos Tribunais - RT, 2006.

SILVA, José Afonso da. Curso de Direito Constitucional Positivo. 24. ed., São Paulo: Malheiros, 2005.

. Ordenação Constitucional da Cultura. São Paulo: Malheiros, 2001.

SOUZA FILHO, Carlos Frederico Marés de. O Renascer dos Povos Indígenas para o Direito. Curitiba: Juruá Editora, 2008.

. O Direito Envergonhado - o direito e os índios no Brasil. Revista IIDH, vol. 15. Costa Rica: Instituto Interamericano de Direitos Humanos, 1990. Disponível em: <http://www.corteidh.or.cr/tablas/R06852-5.pdf>. Acesso em 17 jul. 2014.

SUPREMO TRIBUNAL FEDERAL. Pesquisa de Jurisprudência. Disponível em: <http://www.stf.jus.br>. Acesso em 30 jun. 2014.

SUPERIOR TRIBUNAL DE JUSTIÇA. Pesquisa de Jurisprudência. Disponível em: <http://www.stf.jus.br/> Acesso em: 30 jun. 2014. 